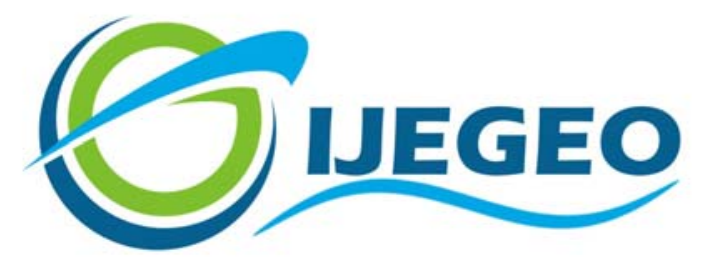

International Journal of Environment and Geoinformatics (IJEGEO) is an international, multidisciplinary, peer reviewed, open access journal.

\title{
A GIS Approach to Evaluate Infrastructure Variables Influencing the Occurrence of Traffic Accidents in Urban Roads
}

\section{Murat Selim Çepni and Ozan Arslan}

\section{Editors}

Prof. Dr. Cem Gazioğlu, Prof. Dr. Dursun Zafer Şeker, Prof. Dr. Ayşegül Tanık, Assoc. Prof. Dr. Şinasi Kaya

\section{Guest Editors}

Assoc. Prof. Dr. Ekrem Tuşat, Asist. Prof. Dr. Fatih Sarı, Prof. Dr. Hakan Karabörk

\section{Scientific Committee}

Assoc. Prof. Dr. Hasan Abdullah (BL), Assist. Prof. Dr. Alias Abdulrahman (MAL), Assist. Prof. Dr. Abdullah Aksu, (TR); Prof. Dr. Hasan Atar (TR), Prof. Dr. Lale Balas (TR), Prof. Dr. Levent Bat (TR), Assoc. Prof. Dr. Füsun Balık Şanlı (TR), Prof. Dr. Nuray Balkıs Çağlar (TR), Prof. Dr. Bülent Bayram (TR), Prof. Dr. Şükrü T. Beşiktepe (TR), Dr. Luminita Buga (RO), Prof. Dr. Z. Selmin Burak (TR), Assoc. Prof. Dr. Gürcan Büyüksalih (TR), Dr. Jadunandan Dash (UK), Assist. Prof. Dr. Volkan Demir (TR), Assoc. Prof. Dr. Hande Demirel (TR), Assoc. Prof. Dr. Nazlı Demirel (TR), Dr. Arta Dilo (NL), Prof. Dr. A. Evren Erginal (TR), Dr. Alessandra Giorgetti (IT), Assoc. Prof. Dr. Murat Gündüz (TR), Prof. Dr. Taşkın Kavzoğlu (TR), Dr. Hakan Kaya (TR), Assoc. Prof. Dr. Kensuke Kawamura (JAPAN), Prof. Dr. Fatmagül Kılıç (TR), Prof. Dr. Ufuk Kocabaş (TR), Prof. Dr. Hakan Kutoğlu (TR), Prof. Dr. Nebiye Musaoğlu (TR), Prof. Dr. Erhan Mutlu (TR), Assist. Prof. Dr. Hakan Öniz (TR), Assoc. Prof. Dr. Hasan Özdemir (TR), Prof. Dr. Haluk Özener (TR), Assoc. Prof. Dr. Barış Salihoğlu (TR), Prof. Dr. Elif Sertel (TR), Prof. Dr. Murat Sezgin (TR), Prof. Dr. Nüket Sivri (TR), Assoc. Prof. Dr. Uğur Şanlı (TR), Assoc. Prof. Dr. Seyfettin Taş (TR), Assoc. Prof. Dr. İ. Noyan Yılmaz (TR), Assist. Prof. Dr. Baki Yokeş (TR), Assist. Prof. Dr. Sibel Zeki (TR). 


\section{Dear colleagues;}

We are very glad to meet you with "International Journal of Environment and Geoinformatics" special issue which is a compilation of proceedings presented in "SELÇUK INTERNATIONAL SCIENTIFIC CONFERENCE ON APPLIED SCIENCES" held on 27-30 September in Antalya/Turkey.

Besides Turkish scientists, The Selçuk ISCAS 2016 brought together Russian, Ukrainian, Kazakhstan, Azerbaijani, Persian, Algerian, Nigerian, Netherlander, Scottish, Liberian, Philippines and Czech Republican scientists. Turkey General Directorate of Land Registry and Cadastre, Republic of Turkey Ministry of Food, Agriculture and Livestock Undersecretary, International Federal of Surveyors (FIG) and International Society for Photogrammetry and Remote Sensing (ISPRS) contribute to The Selçuk ISCAS 2016 at board of director's level.

The Selçuk International Scientific Conference on Applied Sciences (The Selçuk ISCAS 2016) held in Antalya on 27-30, September 2016. The Selçuk ISCAS 2016 is a candidate of one of the most important event in the scientific schedule and tenders a possibility for researchers and academicians who researches on applied sciences. You can find a first class programme of plenary speakers, technical sessions, exhibitions and social events in this book. You will be able to catch up with the developments in Geographical Information Sciences, Information Technology, Environmental Management and Resources, Sustainable Agriculture, Surveying, Photogrammetry and Remote Sensing, meet friends and experience the traditional and fascinating culture of TURKIYE. As an international conference in the field of geo-spatial information and remote sensing, The Selçuk ISCAS 2016 is devoted to promote the advancement of knowledge, research, development, education and training in Geographical Information Sciences, Information Technology, Environmental Management and Resources, Sustainable Agriculture, Surveying, Photogrammetry and Remote Sensing, their integration and applications, as to contribute to the well-being of humanity and the sustainability of the environment. The Conference of Selçuk ISCAS 2016 will provide us an opportunity to examine the challenges facing us, discuss how to support Future Earth with global geo-information, and formulate the future research agenda.

195 scientists from 13 countries attended to the symposium. 105 oral presentations, 40 fast oral presentations and 50 poster presentations are presented during the symposium. 145 oral and fast oral presentations take place in 24 technical sessions in two days. On the other hand, 5 invited speaker presentations held in the plenary session in the first day.

The conference is carried out with the support of the organizations as the Selçuk University, General Directorate of Land Registry and Cadastre, General Directorate Of Agricultural Reform, Turkish Cooperation and Development Agency (TIKA), International Federation of Surveyors (FIG) and International Society for Photogrammetry and Remote Sensing (ISPRS). In addition, the symposium is also supported by the commercial organizations of Paksoyteknik, Mescioğlu, Geogis, Körfez, Tümaş, 4B Ölçüm, GNSS Teknik, Arbiotek ve Anıt Hospital.

Best wishes.

Assoc. Prof. Dr. Ekrem Tuşat

Asist. Prof. Dr. Fatih Sarı

Prof. Dr. Hakan Karabörk 


\section{A GIS Approach to Evaluate Infrastructure Variables Influencing the Occurrence of Traffic Accidents in Urban Roads}

\section{Murat Selim Çepni ${ }^{*}$ and Ozan Arslan}

Kocaeli University, Engineering Faculty, Department of Geomatic Engineering, 41380 Kocaeli, Turkey

Corresponding author.

E-mail: muratselim.cepni@kocaeli.edu.tr

Received: 01 November 2016 Accepted: 30 December 2016

Several studies worldwide have been developed that seek to explain the occurrence of traffic accidents from different perspectives. The analyses have addressed legal perspectives, technical attributes of vehicles and infrastructure as well as the psychological, behavioral and socio-economic components of the road system users. Recently, some analysis techniques based on the use of Geographic Information Systems (GIS) have been used, which allow the generation of spatial distribution maps, models and risk estimates from a spatial perspective. Sometimes analyses of traffic accidents are performed using quantitative statistical techniques, which place significant importance on the evolution of accidents. Studies such as those in references have shown that conventional statistical models are sometimes inadequate to model the frequency of traffic accidents, as they may provide erroneous inferences. GIS approach has been used to explore different spatial and temporal visualization technologies to reveal accident patterns and significant factors relating to vehicle crashes, or as a management system for accident analysis and the determination of hot spots. This paper examines the relationship between urban road accidents and variables related to road infrastructure, environment and traffic volumes. Some accident-prone sections in the city of Kocaeli are specifically identified by GIS tools. Urban road accidents in Kocaeli are a serious problem and it is believed that accidents can be related to infrastructure characteristics. The study aimed to establish the relationship between urban road accidents and the road infrastructure variables and revealed some possible accident prone locations for the period of 2013 and 2015 in Kocaeli city.

Keywords: GIS, Accident, Road, Infrastructure, Spatial Analysis

\section{Introduction}

The process of rapid and unplanned urbanization has resulted in an extraordinary revolution in the growth of motor vehicles world-wide. The alarming increase in morbidity and mortality owing to road traffic incidents over the past few decades is a matter of great concern global scale (Afukaar et al., 2003; Holder et al., 2001; Jacobs et al., 2000). Kocaeli province is the subject of this study as one of the best examples of this situation. The problem of urban road accidents in Kocaeli city is remarkable and has a significant magnitude. For this reason, a technical study of this important issue that examines the relationship between urban road accidents and variables related to road infrastructure, environment, traffic volumes and traffic control is crucial. Some accident-prone sections in the city of Kocaeli are specifically identified by the spatial analysis methods based on GIS. During 2015 there were a total of 2785 road traffic accidents in Kocaeli.

When the traffic accidents are approached using quantitative statistical techniques, the commonly used indicators conceal the problem's determinant variables. Several studies have been developed that investigate to explain the occurrence of traffic accidents from different perspectives. The analyses have addressed legal perspectives, technical attributes of vehicles and infrastructure as well as the psychological, behavioral and socioeconomic components of the traffic users (Flahaut, 2004). There has also been some analysis techniques based on the use of Geographic Information Systems (GIS) which allow the generation of maps, models and risk estimates from a spatial perspective. GIS techniques provide significant tools for maintaining, analyzing, locating and publishing traffic accident-related spatial information. GIS approach has been used to explore different spatial and temporal visualization technologies 
to reveal accident patterns and significant factors relating to accidents.

Spatial data analysis can be viewed as it is one of the most important tools for traffic accident analysis. GIS aided spatial data provides much information to analysts about risky locations, hot spots and critical patterns. (Liang et al., 2005; Erdoğan et al. 2008). Identification of safety deficient locations with GIS will certainly help to decrease the traffic accidents in the region. GIS aided spatial analysis will certainly help to decrease the traffic accidents. But the success of these analyses depends extensively upon accuracy, reliability and comprehensiveness of the traffic accident reports. Recently, there is no consensus among countries which necessary items should be included in traffic accidents reports (Demirel and Akgüngör, 2002). This paper examines the relationship between urban road accidents and variables related to road infrastructure, environment and traffic volumes in Kocaeli. Some accident-prone sections in the city of Kocaeli are specifically identified by GIS spatial analysis tools. It is believed that urban road accidents are a serious problem in Kocaeli and accidents can be related to infrastructure characteristics. The study aimed to establish the relationship between urban road accidents and the road infrastructure variables and revealed some possible accident prone locations for the period of 2013 and 2015 in Kocaeli city. Our analyses, hitherto, aim at the identification of high rate accident locations in the city and safety deficient areas on the highways.

Density analysis was applied to identify the accident prone areas in Kocaeli district during the year of 2015. Both simple and Kernel densities were applied in identifying the accident patterns. The road geometry was measured in the accident prone locations to find out the causes for the accident.

\section{Methodology}

Traffic safety at a roadway is mainly affected by human factors, environmental factors and vehicle characteristics. However, there are other factors such as highway design and design associated geometry (Mungnimit 2001; Bener 2005). Therefore, improving safety on roadways can be achieved through further improvements in a variety of geometric design improvements in roadway safety features. In developing countries, accident number and type of the accident are mainly registered for the drivers to be the cause of accidents regardless of the real cause of the accident. Hence, neither the roadway geometry nor the environment is considered as a cause for accidents, simply because there is an ambiguity of the accident's cause for the authorities.

Highway geometry should be designed for vehicle traffic safety and efficiency. For example, the minimum radius of horizontal curve is defined with design speed, superelevation and side slip friction factor. The authors suggest that all of the design standard values should have a unique safety factor to keep consistent traffic safety. Studies showed that horizontal curves typically have more crash rates than tangent sections. (AASHTO, 2004; Obaidat and Ramadan, 2012) In fact, the use of composite curves (e.g. spiral curves, simple circular curves) could help to mitigate some of the safety problems associated with horizontal curves by providing a smoother and safer path for drivers from tangent to curve position. It is usually beneficial to design horizontal alignments with combinations of maximum curve radii and minimum deflection angles since crash rates tend to increase with the reduced sight distance associated with either a reduced curve radius or an increased deflection angle or curvature.

It is believed that vertical alignment can also lead to higher crash rates due to the reduced sight distance imposed by the crest of a vertical curve. Thus the severity of vertical curvatures should be minimized. It is avoided for the intersections on or near vertical curves represents one of the practical examples in this respect (Hong and Oguchie, 2005; AASHTO, 2004). Roads with poor geometry, with insufficient clear distances, without turn lanes, with poorly laid out intersections or interchanges, pose greater risks to traffic users (TRIP, 2009). Therefore, this paper will focus on hazardous locations in Kocaeli district (Figure 1) and the correlation of accident characteristics with geometrical elements of the roads. The spatial characteristics of road crashes in the city will be analyzed by spatial analysis tools. 


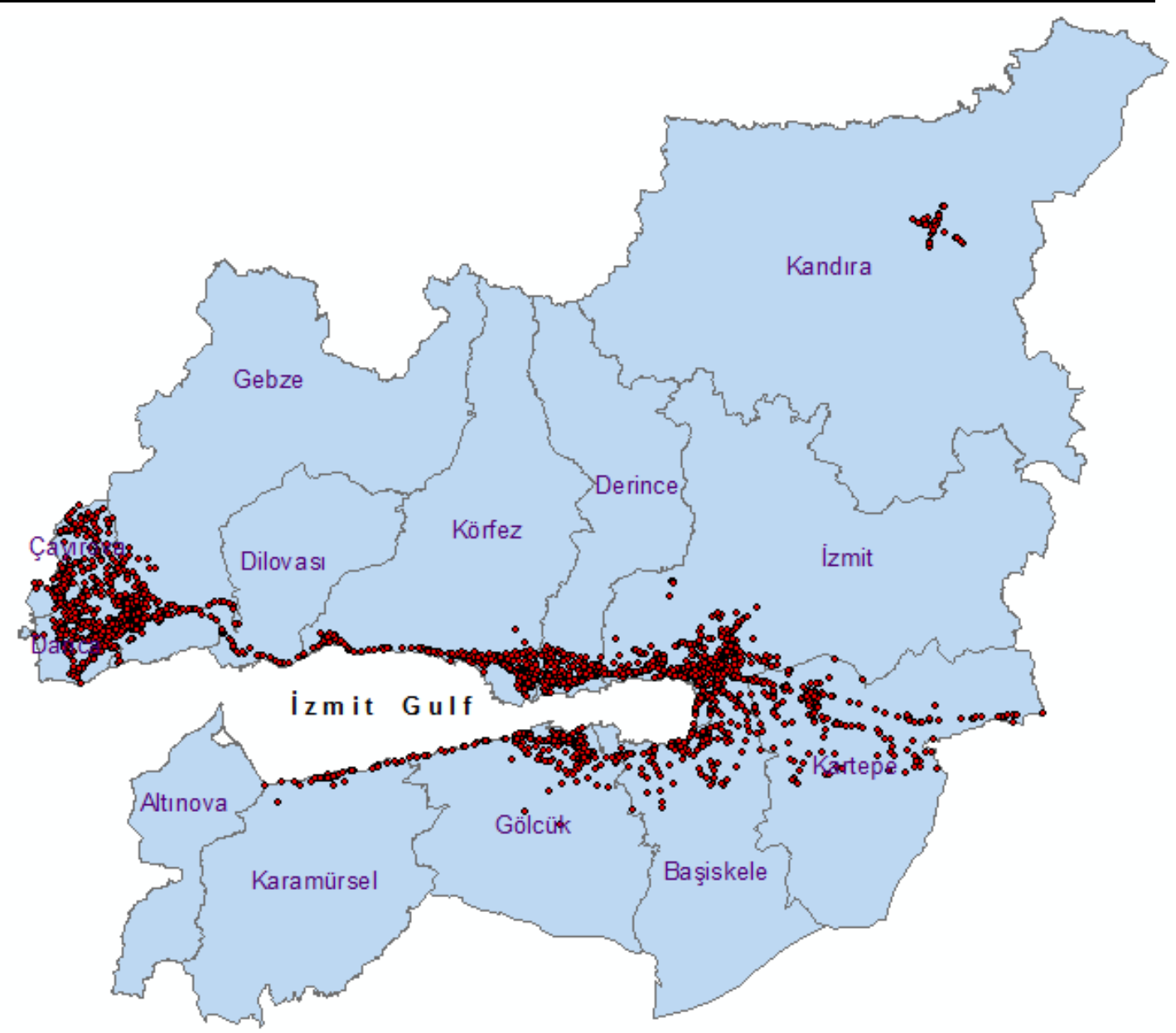

Figure 1: Study area and accident locations for the year of 2015

\section{Accident density pattern analysis}

In order to detect road traffic accident concentration, mainly from the geographic perspective, various methods have been proposed and applied, mainly including spatial autocorrelation methods and kernel density methods. The autocorrelation methods detect whether a given point distribution differs from a random distribution throughout the study area, such as Ripley's K-function, Getis's Gstatistic and Moran's I (Boot and Getis 1988; Ripley 1981; Getis and Ord 1992).

Accident data can simply be represented as geospatial points. A cluster of accidents indicates spatial patterns with high density accidents in that area. Therefore, geospatial clustering method may be able to determine the concentrated areas of accidents.
Geospatial cluster analysis, which is also called geospatial clustering, is an approach to applying spatial clustering techniques on georeferenced data. As widely known, spatial clustering is the process of grouping similar objects based on their distance, connectivity or relative density in space (Han et al. 2001). In addition, clustering methods can discern interesting spatial patterns and features, capture intrinsic relationships between spatial and attribute data. Figure 2 shows the result map of simple density map produced for the accidents occurred in 2015.

Kernel density methods aim at calculating and producing a density surface from point features. Usually, the methods divide the whole area into grid cells, and calculate the density of point features around each output raster cell. The raster cells with high values indicate the accident concentration areas (Fig. 3). 


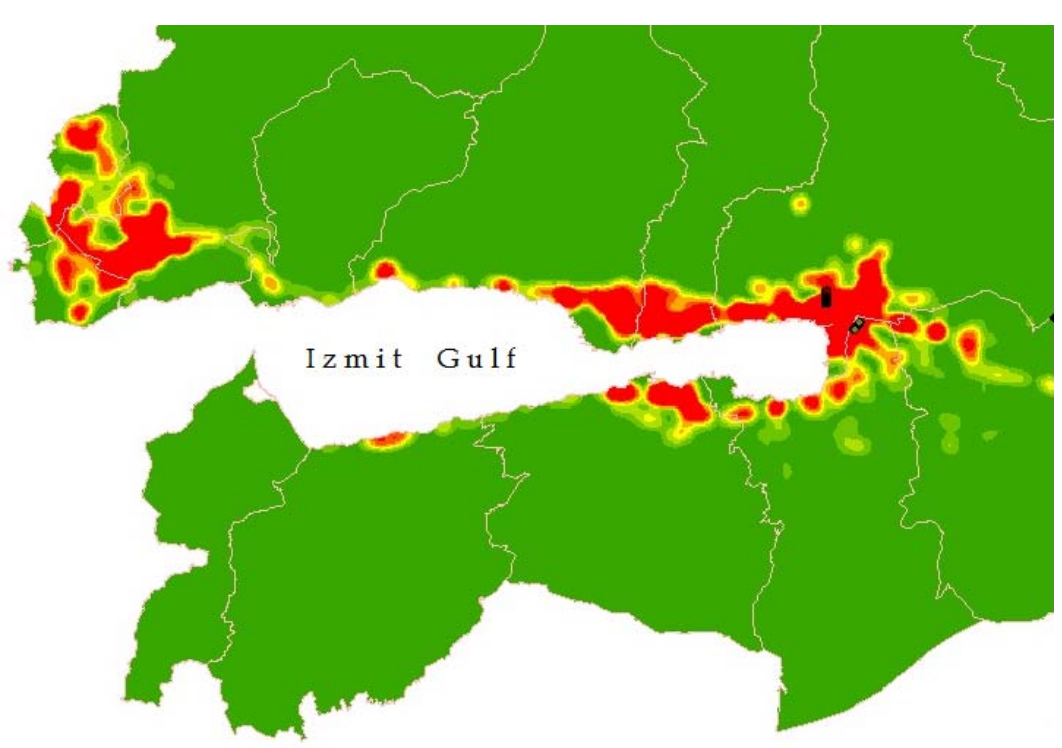

Figure 2: Simple density map for the accidents for the year 2015

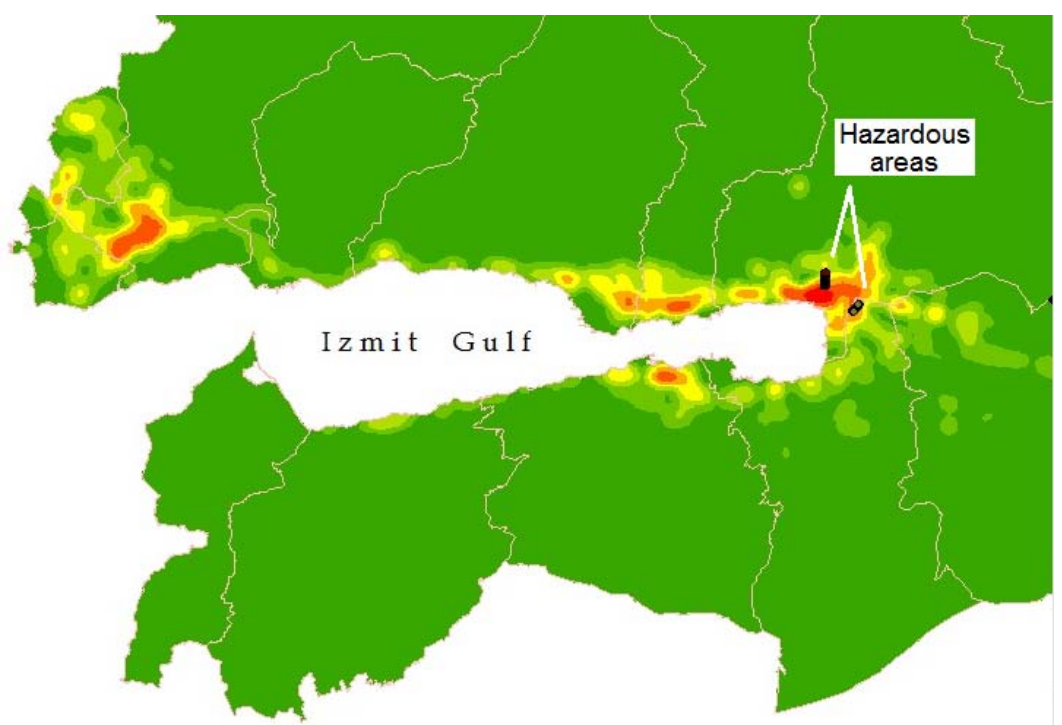

Figure 3: Kernel density map for the accidents for the year 2015

One of our concerns is with whether or not the traffic accidents shown in Figure 3 tend to cluster. To answer this question, we may use the $\boldsymbol{K}$-function method. Positive spatial autocorrelation indicates that accident distribution is clustered, which means the concentration may happen in the study area. Kfunction is one of the evaluation methods. It is defined as the expected number of points within a distance $d$ of an arbitrarily chosen point, divided by the density of points per unit area. We apply the $\boldsymbol{K}$-function method to these assigned points in the region. The result is shown in Figure 4.

The red line indicates the observed $\boldsymbol{K}$-function, and the blue line indicates the expected $\mathrm{K}$ function obtained under the condition that the points are randomly distributed over the region according to the uniform distribution. Comparing the observed $\mathrm{K}$-function with the expected $\boldsymbol{K}$-function, we conclude that the traffic accidents tend to cluster in Kocaeli. 


\section{K Function}

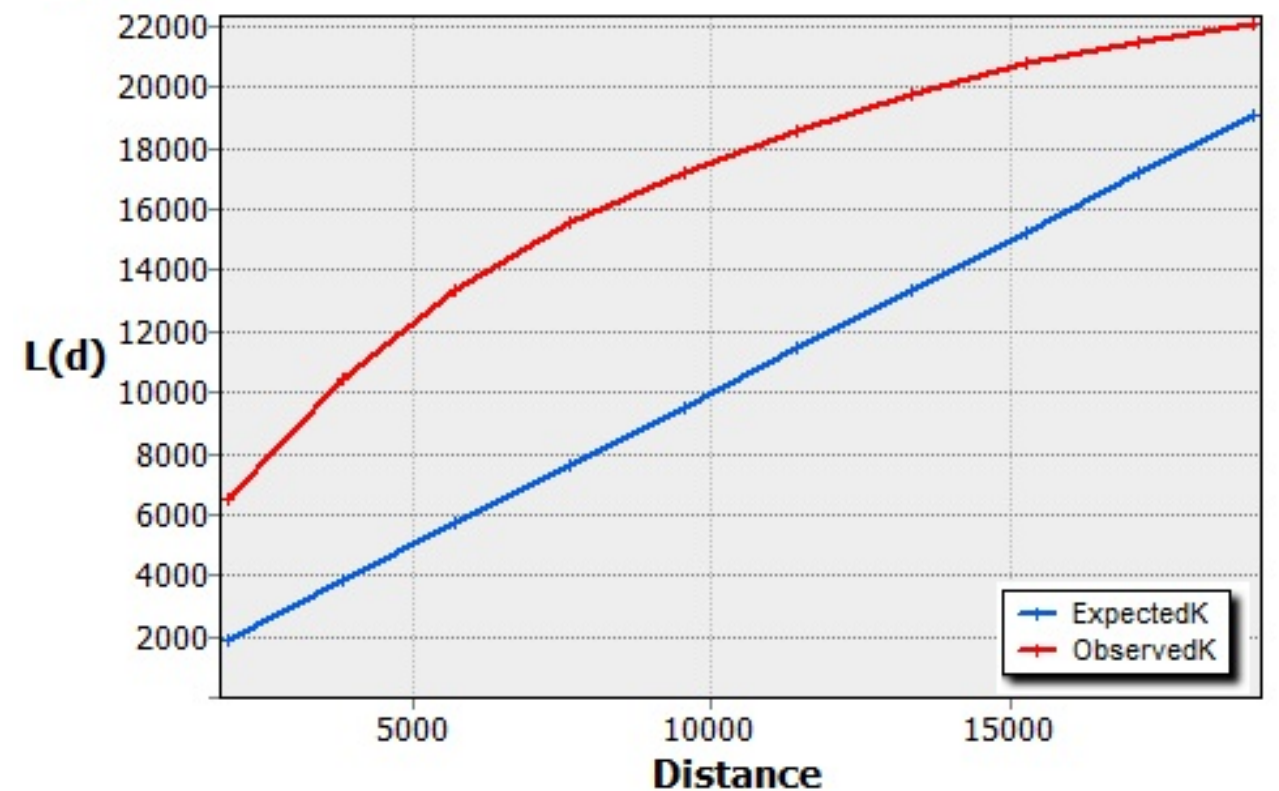

Figure 4: K- function calculated for the accidents (2015)

When the difference between observed and expected $\boldsymbol{K}$-function versus distance is plotted, the mean distance between clusters is found to be approximately $7950 \mathrm{~m}$ (Figure 5).

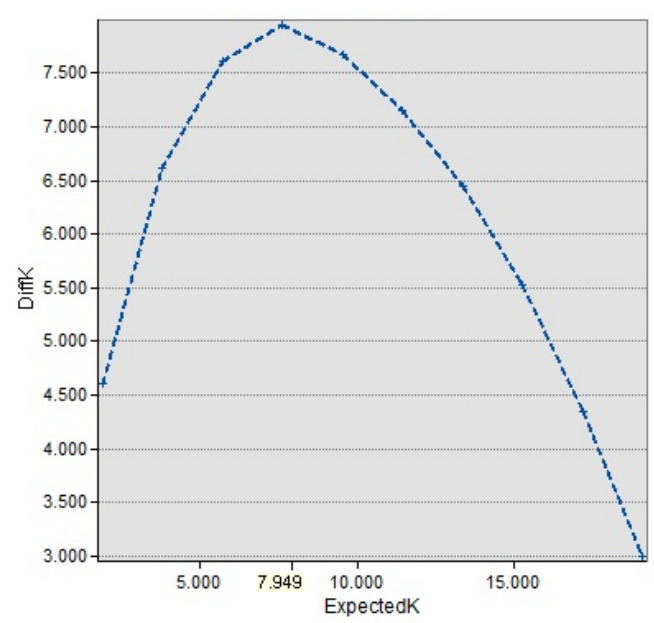

Figure 5: The graph of $\boldsymbol{K}$ - function

Our second concern is with whether or not the traffic accidents tend to gather around some road sections in the region. Naturally if an area on the density map is marked as high risk, that area should be more vulnerable to accidents. Then the road sections located in these risky areas are examined from the geometrical perspectives in the region.

\section{Results and discussions}

Produced density maps show the possible hazardous areas for traffic accidents (Figure 3). Road sections related to these concentration areas are examined considering the geometric elements of the roads to find relationships. Black dots in the figure 3 denote these investigated road sections. One of the most critical road sections in the region is known as "Gazanfer Bilge Avenue" since the profile slope has quite high (18\%) value (Figure 6).

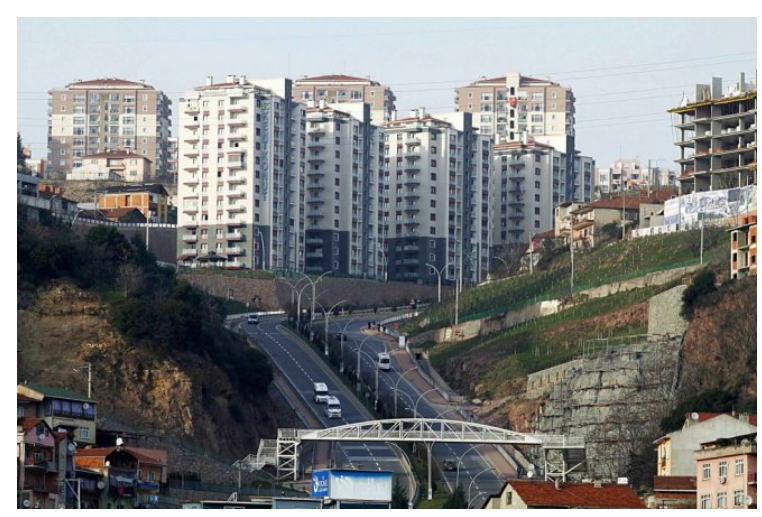

Figure 6: Road section in Gazanfer Bilge Boulevard

This slope value should not be higher than $\% 10$ slope value according to the national highway 
standards. Accident records at the region are denoted as yellow points in figure 7 .

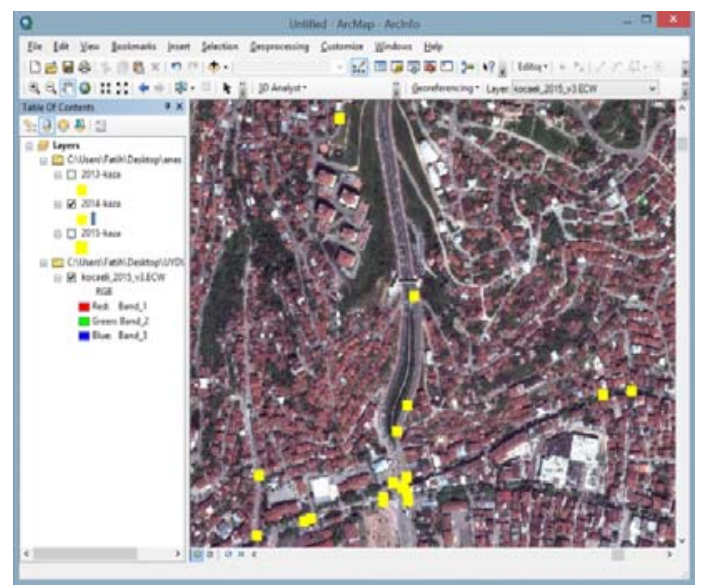

Figure 7: Accidents at the road section in Gazanfer Bilge Avenue

According to a case study (technical report supervised by Çepni, Kocaeli, 2016) which has been conducted to define a new path and to decrease high slope to an acceptable level, topography is not solely factor which should be taken into consideration to a better solution. During the assessments made in surveying along the avenue and evaluating the options, decreasing of slope interpreted as an unfeasible solution for the problem. Despite the extremely high slope, Gazanfer Bilge Avenue is in fact a rational route though to be straight beeline toward northern part from city center. Because of the rough terrain, current alternative routes between downtown and growing settlements (e.g. university campus) are tortuous and time consuming in comparison with the current Gazanfer Bilge Avenue. Therefore, in order to avoid traffic accidents, prescriptive precautions have been recommended instead of the replacement of a new route. The section is also shown in the figure 3 from the geometrical point of view.

The other road section that is marked as high risk on the density map, is known as "DSI intersection" region (Fig. 8).

Accident records at the DSI İntersection region are denoted as yellow points in figure 9. It is believed that poor horizontal road geometry tends to increase accidents in the district. Both horizontal and vertical geometry of DSI
Intersection was also studied in the case study as previously mentioned above.

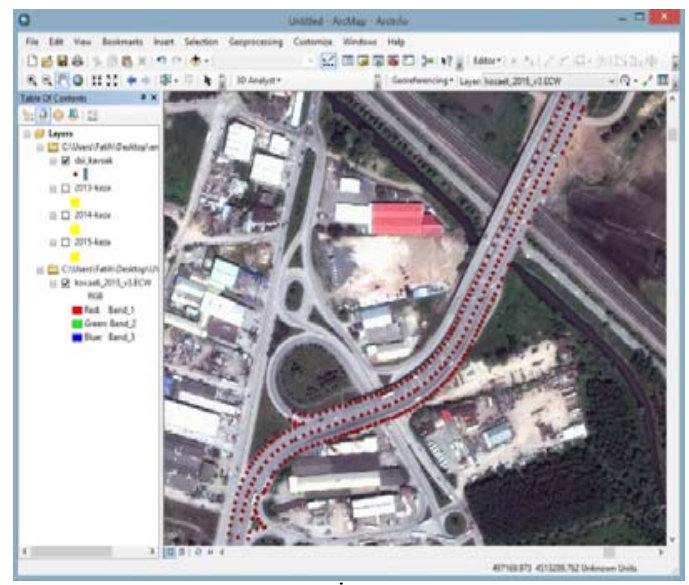

Figure 8: Road section in DSİ intersection

Marked points in Figure 8 were surveyed due to delineated of the roadway segment. Both components of junction were evaluated as inadequate regarding to the national highway standards. The main handicap of roadway design is redundant unified curb located on north south direction. It has been speculated that at the stage of road construction the curves were planned so as to preserve some current buildings. Distance between two horizontal small radius simple curves can be accepted narrow enough, even though flowing speed on the previous section of curb doesn't support this poor geometric conditions. As it can be seen at Figure 9, accidents are therefore occurred in the passage section of curve because of the unexpected sharp bend. Other deficient of the bend is inaccurate transverse slopes on the curve which is known as superelevation slopes. The effect of centrifugal force on vehicles was not able be reduced to an acceptable level due to incorrect superelevation slopes. Thus, DSI intersection is found to be the maximum risk point of the road sections at Kocaeli city. Despite the traffic signs and warnings at the region, DSI intersection has still the most concentrated (high density) accident rates. The exact and radical solution for this intersection is evaluated to remove of the redundant curb in the study. Other suggestions are based on the restoration of geometric features of the roads depending on findings from these analyses of road junction's geometric design. 


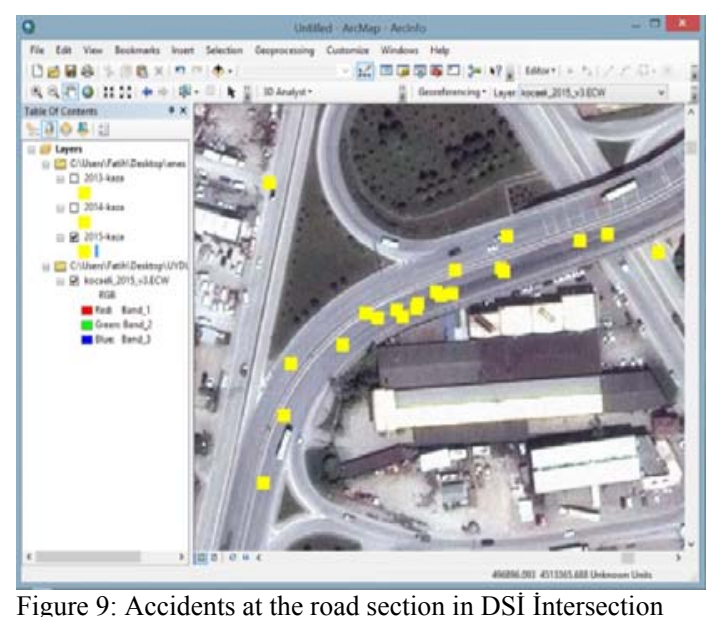

Another road section that is marked as high risk on the density map, is known as "AkmeșeSerdivan bağlantı yolu" region (Figure 10). It is believed that vertical curb geometry and reduced sight distance yielded higher risk for the users.

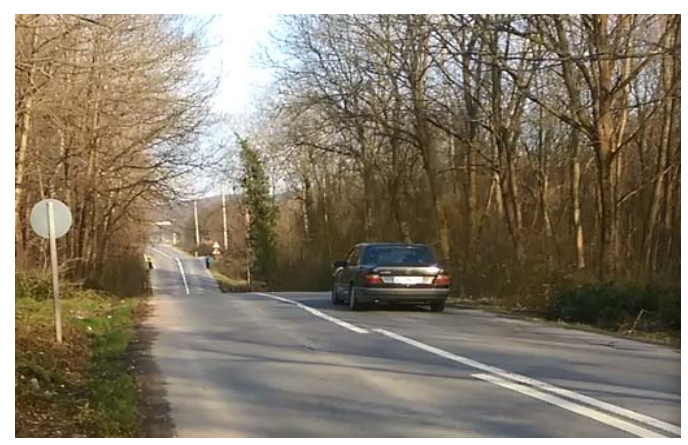

Figure 10: Road section in Akmeşe- Serdivan access road

This vertical curb is a striking sample for obstructing of vehicle's (or driver's) sight in the concavity. As it can be seen from the Fig.10, vehicles on the road are not able to be seen by drivers at this "gap" area. Hence, the journey on this road segment carries significant accident risks depending on lack of visibility. Terrain model analysis which was performed in the case study shows that the dip caused to sightless can be prevented readily. Examination of profiles yielded that the cavity at vertical curve on the road is rectifiable with a small amount filling. It is known that roadways which have many "blind" points as in our example can easily be fixed without high costs and avoided from accidents caused by concavity.

\section{Conclusion}

GIS-based approach has been a popular tool for visualization of accident data and analysis of hot spots in motorways. Accident analysis studies aim at the identification of high rate accident locations and safety deficient areas on the motorways. A GIS-based approach was used to tackle the traffic safety issues in urban roads in Kocaeli city. This study aims at highlighting the influential geometrical factors to accident occurrence at hazardous locations of local urban roads in the region. The paper will focus on identifying hazardous locations using spatial density functions in urban areas and the correlation of accident characteristics with geometrical elements of the roads. When the road sections (or spot locations) containing the studied hazardous locations are determined, these areas are investigated from the geometrical design standards. It is worth mentioning here that further improvements for geometric design of the detected road sections can reduce fatal accident rates in the region.

\section{References}

AASHTO. (2004). A Policy of Geometric Design of Highways and Streets, American Association of State Highway and Transportation Officials (AASHTO), Washington, D.C.

Afukaar FK, Antwi P, Ofosu-Amaah S.(2003): Pattern of road traffic injuries in Ghana: Implications for control. Inj Control Saf Promot; 10:69-76.

Bener, A. (2005). The Neglected Epidemic: Road Traffic Accidents in a Developing Country, State of Qatar, International Journal of Injury Control and Safety Promotion, 12 (1), March, pp. 45-47.

Boots, B.N. and Getis, A. (1988). Point pattern analysis. Sage Publications, Newbury Park, CA.

Cantillo,V., Garcés, P. and Márquez, L. (2016). Factors influencing the occurrence of traffic accidents in urban roads: A combined GISEmpirical Bayesian approach, DYNA 83 (195), pp. 21-28. February, Medellín. ISSN 0012-7353 Printed, ISSN 2346-2183 Online

Demirel, A. and Akgungor, A.P. (2002): The Importance of Reports in The Accident Analyses, Problems in Application and Recommendations for Solution, Gazi University, International Traffic and Road 
Safety Congress, Ankara, Türkiye (in Turkish).

Erdoğan, S. Yılmaz, İ., Baybura, T. and Güllü, M (2008). Geographical information systems aided traffic accident analysis system case study: City of Afyonkarahisar. Accident Analysis and Prevention, 40:174181.

Flahaut, B. (2004). Impact of infrastructure and local environment on road unsafety: Logistic modeling with spatial autocorrelation. Accident Analysis and Prevention, 36, pp. 1055-1066.

Getis, A. and Ord, J.K. (1992). The Analysis of Spatial Association by Use of Distance Statistics. Geographical Analysis. 24, pp. 189-206.

Holder Y, Peden M, Krug E., Lund J, Gururaj G. and Kobusingye O. (2001): Injury surveillance guidelines. Geneva:World Health Organization; 2001.

Hong, S. and Oguchie, T. (2005). Evaluation of Highway Geometric Design and Analysis of Actual Operating Speed. Journal of the Eastern Asia Society for Transportation Studies, 6, pp. 1048-1061.

Jacobs G, Aaron-Thomas A. (2000): Astrop A. Estimating global road fatalities. TRL Report 445. London:Transport Research Laboratory.

Liang, L.Y., Mo'soem, D.M. and Hua, L.T. (2005). Traffic accident application using geographic information system. Journal of the Eastern Asia Society for Transportation Studies. 6, pp.3574-3589.

Mungnimit, S. (2001). Road Traffic Accident Losses. Transport and Communications Policy and Planning Bureau, Ministry of Transport and Communications, Thailand.

Obaidat, M.T. and Ramadan, T.M. (2012). Traffic Accidents at Hazardous Locations of Urban Roads. Jordan Journal of Civil Engineering, Volume 6, No. 4,

Okabe, A. and Yamada, I. (2010). The $K$ Function Method on a Network and Its Computational Implementation. Geographical Analysis. 33, 271-290.

Ripley, B.D. (1981). Spatial Statistics. John Wiley and Sons, New York.

TRIP. (2009). Future Mobility in West Virginia: Meeting the State's Need for Safe and Efficient Mobility, U.S. Department of Transportation, Washington, D.C. 